\title{
RESPON BAWANG MERAH (Allium ascalonicum. L) TERHADAP PEMBERIAN TRICHOKOMPOS TKKS TERFORMULASI DAN PUPUK NITROGEN PADA LAHAN GAMBUT
}

\author{
Azrida Syamsi $^{1}$, Nelvia ${ }^{2}$, Fifi Puspita ${ }^{2}$ \\ 1. Mahasiswi Pasca Fakultas Pertanian Universitas Riau \\ 2. Dosen Pasca Sarjana Universitas Riau \\ e-mail: asyamsi 79@gmail.com
}

\begin{abstract}
ABSTRAK
Penelitian bertujuan untuk mempelajari interaksi pemberian Trichokompos TKKS terformulasi dan pupuk nitrogen, pengaruh utama keduanya terhadap pertumbuhan dan produksi bawang merah (Allium ascalonicum. L) pada lahan gambut serta serapan hara N. Penelitian dilakukan secara ekperimen dalam bentuk faktorial 4 x 3 disusun menggunakan Rancangan Acak Lengkap (RAL). Faktor pertama yaitu Trichokompos TKKS terformulasi yang terdiri dari 4 taraf $(15,20,25$, dan 30 ton/ha) dan faktor ke dua yaitu pupuk nitrogen yang terdiri dari 3 taraf (150, 250, dan $350 \mathrm{~kg} / \mathrm{ha}$ ). Parameter yang diamati adalah tinggi tanaman, jumlah anakan dan bobot segar umbi per rumpun sampel. Hasil penelitian menunjukkan bahwa interaksi Trichokompos TKKS terformulasi 30 ton/ha dan pupuk nitrogen $350 \mathrm{~kg} \mathrm{~N} /$ ha meningkatkan bobot segar umbi per rumpun sampel secara nyata. Peningkatan dosis Trichokompos TKKS terformulasi dari $15 \mathrm{ke} 30$ ton/ha meningkatkan tinggi tanaman, jumlah anakan dan bobot segar umbi per rumpun sampel. Peningkatan dosis pupuk nitrogen dari $150 \mathrm{ke} 350 \mathrm{~kg}$ N/ha meningkatkan tinggi tanaman dan bobot segar umbi per rumpun sampel.
\end{abstract}

Kata kunci: Bawang merah,Trichokompos TKKS terformulasi, pupuk nitrogen, gambut

\section{PENDAHULUAN}

Bawang merah merupakan salah satu komoditi tanaman hortikultura yang tergolong sayuran rempah, memiliki arti penting bagi masyarakat Indonesia baik ditinjau dari segi ekonomi maupun kandungan gizinya. Bawang sebagai sumber beberapa vitamin dan mineral seperti 1,5 g protein, 0,3 g lemak, 9,2 $\mathrm{g}$ karbohidrat, $36 \mathrm{mg}$ kalsium, 40,0 mg besi, 0,03 $\mathrm{mg}$, vitamin $\mathrm{B}, 2,0 \mathrm{mg}$ vitamin $\mathrm{C}$, dan air $88 \mathrm{~g}$ setiap $100 \mathrm{~g}$ bawang merah (Samsudin, 1986 dalam Anshar, 2002).

Permintaan konsumen terhadap bawang merah terus meningkat seiring dengan meningkatnya jumlah penduduk dan tumbuhnya industri-industri berbahan baku bawang merah khususnya di Provinsi Riau. Sedangkan produksi bawang merah di Riau sangat rendah yaitu 12 ton/tahun (BPS, 2014). Untuk memenuhi kebutuhan bawang merah untuk masyarakat Riau masih harus didatangkan dari daerah lain seperti Sumatra Barat, Sumatra Utara, Jawa maupun impor dari negara lain. Oleh karena itu perlu peningkatan produksi bawang merah.

Peningkatan produksi bawang merah dapat dilakukan melalui intensifikasi dan ekstensifikasi. Ekstensifikasi budidaya bawang merah dapat dilakukan pada lahan gambut, karena memiliki sifat fisik yang gembur sehingga dapat mendukung perkembangan umbi bawang merah. Selain itu Riau memiliki lahan gambut terluas di Sumatera yaitu 3.867.414 ha (BBSDLP, 2011) atau $60,1 \%$ dari luas lahan gambut Sumatera, yaitu 6.436.649 ha (Badan Penelitian dan Pengembangan Pertanian, 2011). Dinas Pertanian Tanaman Pangan Provinsi Riau dalam Murniati, et al. (2010) menyatakan bahwa lahan gambut yang potensial untuk pengembangan tanaman pangan seluas 878.751 ha dan baru termanfaatkan $36 \%$ (31.650 ha). Namun pengembangan budidaya bawang merah di lahan gambut memiliki kendala terutama sifat kimia tanah gambut.

Tanah gambut memiliki $\mathrm{pH}$ rendah, kejenuhan basa $(\mathrm{KB})$ rendah, kapasitas tukar kation (KTK) tinggi serta memiliki kandungan 
hara makro terutama $\mathrm{N}, \mathrm{P}, \mathrm{K}, \mathrm{Ca}$, dan $\mathrm{Mg}$ serta hara mikro $\mathrm{Fe}, \mathrm{Cu}, \mathrm{Zn}$, juga rendah (Nelvia, 2009). Sementara itu, untuk melangsungkan pertumbuhan dan produksi bawang merah memerlukan unsur hara makro dan mikro yang cukup dan seimbang. Untuk meningkatkan ketersediaan hara tersebut dapat dilakukan melalui pemberian pupuk organik dan anorganik. Salah satu pupuk organik yang potensial digunakan adalah Trichokompos tandan kosong kelapa sawit (TKKS) yang dikomposkan dengan menggunakan Trichoderma sp sebagai dekomposer.

Kompos TKKS mengandung hara lengkap dan ketersediaan bahan organiknya melimpah di Provinsi Riau (Nelvia et al., 2012). Wahyono et al. (2003) dalam Nelvia et al. (2012) melaporkan bahwa kompos TKKS mengandung $\mathrm{N}>1,5 \%$; $\mathrm{P}$ $>0,3 \% ; \mathrm{K}>2,00 \%$; $\mathrm{Ca}>0,72 \% ; \mathrm{Mg}>0,4 \%$; bahan organik $>50 \%$, nisbah $\mathrm{C} / \mathrm{N} 15,03$ dan 45$50 \%$ air. Hasil penelitian Yulia, et al. (2011) tentang aplikasi pupuk organik pada tanaman caisim menunjukkan bahwa kompos tandan kosong kelapa sawit (TKKS) lebih baik dari jenis pupuk organik lainnya. Nelvia, et al. (2012) melaporkan bahwa pemberian kompos tandan kosong kelapa sawit $10-15$ ton/ha, meningkatkan jumlah akar efektif sekitar 50 $160 \%$, Jumlah dan persentase polong bernas masing-masing $72-79 \%$ dan bobot biji kering per plot 151-115\%. Untuk meningkatkan kualitas Trichokompos TKKS yang dihasilkan, maka dilakukan pengkayaan dengan penambahan zeolit dan tepung tapioka yang disebut Trichokompos TKKS terformulasi. Trichokompos TKKS terformulasi diharapkan mampu meningkatkan ketersediaan unsur hara baik makro dan mikro di dalam tanah.

Hasil penelitian Ichwan (2007) menunjukkan bahwa aplikasi Trichokompos pada tanaman cabai (Capsicum annuum L.) dengan dosis 20 ton/ha menghasilkan tinggi tanaman, jumlah buah per tanaman dan berat buah per tanaman cabai merah tertinggi. Hasil penelitian Anom (2008) menunjukkan pemberian Trichokompos jerami padi dengan dosis 20 ton/ha memberikan efek terbaik pada pertumbuhan dan hasil tanaman sawi. Penelitian Silaban et al. (2014) tentang aplikasi formulasi Trichokompos berbasis limbah sawit pada bibit okulasi karet (Hevea brasiliensis) di medium gambut menunjukkan bahwa pemberian Trichokompos memberikan pengaruh nyata terhadap pertambahan tinggi bibit dan jumlah daun.

Penambahan pupuk an organik khususnya pupuk nitrogen untuk pertumbuhan dan produksi bawang merah di lahan gambut sangat dibutuhkan karena nitogen $(\mathrm{N})$ merupakan unsur penting dalam beberapa senyawa yang ada di dalam sel tanaman.

Nitrogen dibutuhkan tanaman dalam jumlah yang lebih besar yang berfungsi sebagai penyusun protein, enzim dan vitamin. Nitrogen juga berperan dalam pembentukan klorofil atau zat hijau daun yang digunakan untuk proses fotosintesis. Unsur $\mathrm{N}$ dalam jumlah yang cukup akan memperlancar proses metabolisme tanaman dan akhirnya akan mempengaruhi pertumbuhan organ-organ seperti batang, daun dan akar tanaman bawang merah menjadi lebih baik.

Ketersediaan nitrogen bagi tanaman pada lahan gambut masih tergolong rendah, walaupun kadar $\mathrm{N}$ total umumnya relatif tinggi karena berasal dari N-organik. Sehingga kebutuhan nitrogen untuk mendukung proses pertumbuhan dan produksi bawang merah yang ditanam pada lahan gambut belum tercukupi.

Kebutuhan hara nitrogen optimum untuk bawang merah yaitu 150 - $300 \mathrm{~kg} / \mathrm{ha}$ (Napitulu dan Winarto, 2010). Hasil penelitian Napitulu dan Winarto (2010) menunjukkan bahwa penambahan pupuk nitrogen $250 \mathrm{~kg} / \mathrm{ha}$ menghasilkan bobot kering umbi bawang merah tertinggi yaitu 64,69 g/rumpun. Hasil penelitian di Garut yang dilakukan oleh Sunarlim (1998) menunjukkan bahwa pemupukan $\mathrm{N}$ meningkatkan semua tolok ukur pertumbuhan tanaman kedelai, kecuali jumlah dan bobot bintil akar.

Kesuburan tanah gambut dapat ditingkatkan dengan pemberian Trichokompos TKKS terformulasi dan pupuk nitrogen. Namun dosis Trichokompos TKKS terformulasi dan pupuk nitrogen yang tepat bagi tanaman bawang merah belum diketahui khususnya untuk lahan gambut Provinsi Riau. Penggunaan kedua pupuk ini diharapkan dapat terjadi interaksi yang akhirnya 
dapat menghasilkan pertumbuhan dan produksi bawang merah yang lebih baik dan optimal di lahan gambut.

Berdasarkan uraian di atas mendorong peneliti untuk melakukan penelitian tentang “

Respons Bawang Merah (Allium ascalonicum. L) Terhadap Pemberian Trichokompos TKKS Terformulasi dan Pupuk Nitrogen pada Lahan Gambut “.

\section{METODOLOGI PENELITIAN}

Penelitian ini merupakan penelitian lapangan yang dilaksanakan pada bulan Oktober hingga Desember 2014 di lahan gambut saprik Rimbo panjang Kecamatan Tambang Kabupaten Kampar. Bahan-bahan yang digunakan dalam penelitian adalah benih bawang merah varietas Bauji berasal dari daerah Nganjuk Jawa Timur, Trichokompos TKKS terformulasi, Urea,TSP dan $\mathrm{KCl}$, mulsa, insektisida Curaccron dan fungisida Dhithane M-45 serta bahan kimia untuk analisis laboratorium.

Alat-alat yang digunakan antara lain adalah: timbangan analitik, jangka sorong, oven, $\mathrm{pH}$ meter, Autoclave, Spectrophotometer, destilasi, destruksi, AAS (Atomic Absorption Spectrophotometer), gelas ukur papan merek dan alat-alat lainnya yang mendukung penelitian.

Penelitian dilakukan secara ekperimen dalam bentuk faktorial 4 x 3 menggunakan Rancangan Acak Lengkap (RAL) Faktor pertama adalah pupuk Trichokompos TKKS terformulasi (T) yang terdiri dari empat taraf yaitu :

$\mathrm{T} 1=15$ ton $/$ ha Trichokompos TKKS terformulasi

$\mathrm{T} 2=20$ ton $/$ ha Trichokompos TKKS terformulasi

$\mathrm{T} 3=25$ ton $/$ ha Trichokompos $\mathrm{TKKS}$ terformulasi

$\mathrm{T} 4=30$ ton/ha Trichokompos TKKS terformulasi

Faktor ke dua adalah pupuk nitrogen (N) terdiri dari tiga taraf sebagai berikut :

$\mathrm{N} 1=150 \mathrm{~kg} \mathrm{~N} / \mathrm{ha}$

$\mathrm{N} 2=250 \mathrm{~kg} \mathrm{~N} / \mathrm{ha}$

$\mathrm{N} 3=350 \mathrm{~kg} \mathrm{~N} / \mathrm{ha}$

Model linier yang digunakan adalah:

Dimana:
Yijk $=\mu+\alpha i+\beta j+(\alpha \beta) i j+€ i j k$

Disini:

Yijk: nilai pengamatan pada satuan percobaan ke-k yang memperoleh perlakuan ij (taraf ke-i dari faktor dosis Trichokompos terformulasi taraf ke-j dari faktor dosis pupuk nitrogen).

$\mu \quad$ : nilai tengah populasi

ai : pengaruh aditif faktor pupuk Trichokompos TKKS terformulasi pada taraf ke-i

$\beta j$ : pengaruh aditif faktor pupuk nitrogen pada taraf ke-j

$\alpha \beta \mathrm{ij}$ : Pengaruh Interaksi antara faktor Trichokompos TKKS terformulasi pada taraf ke-i dan pupuk nitrogen taraf ke-j

€ijk: pengaruh galat Trichokompos TKKS terformulasi taraf ke-i, faktor pupuk nitrogen taraf ke-j dan ulangan taraf ke-k

$\mathrm{i}=1,2,3,4 \mathrm{j}=1,2,3 \quad \mathrm{k}=1,2,3$

Data hasil pengamatan tinggi tanaman, jumlah anakan, jumlah umbi berdasarkan kriteria diamaeter, bobot segar umbi per sampel, bobot kering umbi per sampel, bobot umbi per meter persegi dianalisis secara statistik menggunakan analisis ragam. Jika hasil sidik ragam berpengaruh nyata diuji lanjut menggunakan uji Duncan New Multiple Range Test (DNMRT) pada taraf $5 \%$. Serapan hara $N$ dianalisis secara deskriptif dan disajikan dalam bentuk tabel.

Penelitian di awali dengan pengolahan tanah dengan cara mencangkul tanah kemudian dilanjutkan dengan pembuatan plot dengan ukuran $1 \times 1,5 \mathrm{~m}$ dengan jumlah total 36 plot dan jarak antar plot $30 \mathrm{~cm}$. Selanjutnya di beri perlakuan berupa pupuk Trichokompos terformulasi sesuai dosis perlakuan yang diaplikasikan seminggu sebelum tanam. Pupuk nitrogen diberikan pada umur 15, 30, 45 HST masing-masing $1 / 3$ dosis perlakuan.

Bibit yang digunakan varietas Bauji dengan diameter sedang, sebelum ditanam bibit dipotong 1/3 bagian atas kemudian diberi fungisida Dhitane M-45 yang dilarutkan sebanyak $5 \mathrm{gr} / \mathrm{l}$ air. Bibit ditanam dengan cara membenamkan kedalam lobang tanam dengan kedalaman 2/3 bagian ke dalam tanah dengan jarak tanam $20 \mathrm{x}$ $20 \mathrm{~cm}$. Setelah penanaman dilakukan penyiraman yang dilakukan dua kali sehari pagi dan sore hari tergantung keadaan cuaca. Penyiangan dilakukan 
dengan cara mencabut gulma yang tumbuh dalam lobang tanam yang diberi mulsa dan di sekeliling areal penelitian dengan alat cangkul. Penyiangan dilakukan dengan interval seminggu sekali.

Penyulaman dilakukan untuk mengganti tanaman yang sakit atau mati dilakukan selama tanaman inti belum berumur dua minggu. Pengendalian hama dilakukan dua minggu sekali dengan menyemprotkan insektisida Curaccron dengan dosis $10 \mathrm{ml} /$ liter air, sedangkan pengendalian penyakit tidak dilakukan karena diharapkan dengan pemberian Trichokompos TKKS terformulasi dapat mengendalikan penyakit.

Panen dilakukan setelah tanaman berumur 55 hari setelah tanam. ciri-ciri $60 \%$ batang telah lemas dan daun menguning. Umbi lapis terlihat penuh padat berisi harna kulit telah mengkilap atau memerah. Cara panen adalah mencabut seluruh bagian tanaman.

\section{HASIL DAN PEMBAHASAN \\ Tinggi tanaman $(\mathrm{cm})$ \\ Tinggi tanaman}

Hasil sidik ragam menunjukkan bahwa pemberian Trichokompos TKKS terformulasi dan pupuk nitrogen berpengaruh nyata terhadap tinggi tanaman bawang merah. Interaksi pupuk Trichokompos TKKS terformulasi dengan pupuk nitrogen berpengaruh tidak nyata terhadap tinggi tanaman bawang merah. Tinggi tanaman bawang merah setelah dilakukan uji lanjut dengan DNMRT taraf 5\% disajikan pada Tabel 1.

Tabel 1.Tinggi tanaman bawang merah $(\mathrm{cm})$ umur 45 HST dengan pemberian Trichokompos TKKS terformulasi dan pupuk nitrogen pada lahan gambut

\begin{tabular}{lllll}
\hline \multirow{2}{*}{$\begin{array}{c}\text { Tricho- } \\
\text { kompos } \\
\text { (ton/ha) }\end{array}$} & \multicolumn{4}{c}{ Nitrogen(kg) } \\
\cline { 2 - 5 } & 150 & 250 & 350 & Rata-rata \\
\hline 15 & 28,99 & 24,89 & 27,55 & $27,15 \mathrm{~b}$ \\
20 & 26,33 & 28,05 & 28,72 & $27,70 \mathrm{~b}$ \\
25 & 25,39 & 26,89 & 30,05 & $27,45 \mathrm{~b}$ \\
30 & 30,00 & 28,22 & 32,22 & $30,15 \mathrm{a}$ \\
\hline Rata-rata & $27,68 \mathrm{~b}$ & $27,01 \mathrm{~b}$ & 29,63 & \\
\hline
\end{tabular}

Angka-angka yang diikuti oleh huruf kecil yang sama pada kolom dan baris yang sama berbeda tidak nyata menurut uji Duncan pada taraf 5\%.

Tabel 3 memperlihatkan bahwa pemberian Trichokompos TKKS terformulasi dan pupuk nitrogen tidak terjadi interaksi secara nyata terhadap tinggi tanaman bawang merah, namun pemberian Trichokompos TKKS terformulasi 30 ton/ha diikuti pupuk nitrogen $350 \mathrm{~kg} / \mathrm{ha}$ cenderung meningkatkan tinggi tanaman sebesar $29,44 \%$ dibandingkan dengan pemberian Trichokompos TKKS terformulasi dosis 15 ton/ha diikuti pupuk nitrogen $250 \mathrm{~kg} / \mathrm{ha}$. Tidak terjadinya interaksi disebabkan ketersediaan hara nitrogen dalam tanah cukup tinggi (Hasil analisa tanah awal) sehingga penambahan unsur $\mathrm{N}$ baik dari Trichokompos TKKS terformulasi maupun dari pupuk nitrogen sudah tidak direspon lagi.

Tinggi tanaman yang dihasilkan $32,22 \mathrm{~cm}$ masih dibawah tinggi tanaman pada deskripsi. Hal ini disebabkan faktor lingkungan terutama curah hujan yang tinggi pada saat penelitian. Curah hujan yang tinggi menyebabkan unsur hara tercuci sehingga kurang termanfaatkan oleh tanaman. Menurut Lingga dan marsono (2005) jika hujan turun menyebabkan pupuk yang diberikan tercuci bersama air perkolasi.

Hasil penelitian Purbiati, et al. (2010) tentang uji adaptasi varietas bawang merah di lahan gambut Kalimantan Barat menunjukkan bahwa bawang merah varietas Bauji yang diberi pupuk dasar kandang ayam ditambah pupuk organik pabrik 10 ton/ha pada umur 30 hari setelah tanam (HST) menghasilkan tinggi tanaman $18,72 \mathrm{~cm}$. Hidayat, et al. (2011) melaporkan bahwa bawang merah varietas Bauji yang ditanam di Brebes pada musim kemarau dihasilkan tinggi tanaman lebih tinggi dibandingkan di Tegal dan di Nganjuk yaitu dengan tinggi tanaman berturut-turut 39,93 $\mathrm{cm}, 33,07 \mathrm{~cm}$ dan $33,40 \mathrm{~cm}$.

Pemberian Trichokompos TKKS terformulasi 30 ton/ha nyata meningkatkan tinggi bawang merah $11 \%$ dibandingkan dengan Trichokompos TKKS terformulasi dosis 15 ton/ha. Hal ini disebabkan Trichokompos TKKS terformulasi mengandung hara lengkap antara lain kadar air $48,6 \%, \mathrm{~N} 2,10 \%$, P2O5 2,16\%, K2O 2,49\%, Mg 
0,55\%, dan $\mathrm{CaO} 0,99 \%$, C-organik 24,4\%, C/N 11,7 dan $\mathrm{pH} 6,8$.

Lengkapnya kandungan unsur hara dalam Trichokompos TKKS terformulasi dapat memperlancar proses fisiologis yang mendukung proses metabolisme dapat berlangsung dengan baik sehingga dapat mendorong pertumbuhan tanaman menjadi lebih baik.

Peningkatan proses fisiologis seperti proses fotosintesis akan meningkatkan jumlah fotosintat yang dihasilkan. Hasil fotosintat akan dimetabolisme untuk pembentukan senyawa organik diantaranya asam amino dan dilanjutkan dengan pembentukan protein yang mendukung pertumbuhan tanaman.

Hasil penelitian Ichwan (2007) menunjukkan bahwa dosis Trichokompos sebesar 20 ton/ha memberikan tinggi tanaman cabe merah tertinggi, namun peningkatan hasil tanaman cabe merah masih dapat dilakukan dengan peningkatan dosis Trichokompos lebih dari 20 ton/ha. Menurut Dahlan, et al. (2015) Pemberian Trichokompos TKKS 9 ton/ha dapat meningkatkan tinggi tanaman Pakcoy (Brassica rapa L.) pada tanah Inseptisol.

Pemberian pupuk nitrogen dosis $350 \mathrm{~kg} / \mathrm{ha}$ nyata meningkatkan tinggi tanaman $9 \%$ dibandingkan dosis $250 \mathrm{~kg} / \mathrm{ha}$. Hal ini disebabkan pertumbuhan tinggi tanaman merupakan pertumbuhan vegetatif yang dipengaruhi ketersediaan unsur hara terutama unsur nitrogen. Lingga dan Marsono (2006) menyatakan bahwa peranan nitrogen penting dalam mendorong pertumbuhan vegetatif tanaman. Prasetya, et al . (2009) juga melaporkan bahwa unsur nitrogen bermanfaat untuk pertumbuhan vegetatif tanaman yaitu pembentukan sel-sel baru seperti daun, cabang, dan mengganti sel-sel yang rusak. Nitrogen merupakan salah satu unsur penyusun khlorofil.

Menurut Lakitan (2001) peningkatan khlorofil akan meningkatkan aktifitas fotosintesis sehingga fotosintat yang dihasilkan lebih banyak, maka pertumbuhan tinggi tanaman akan meningkat. Napitulu dan Winarto (2010) menyatakan tanaman bawang merah dalam pertumbuhan vegetatifnya membutuhkan pupuk nitrogen yang tinggi.

\section{Jumlah anakan}

Hasil sidik ragam menunjukkan bahwa pemberian Trichokompos TKKS terformulasi berpengaruh nyata terhadap jumlah anakan tanaman bawang merah, pemberian pupuk nitrogen dan interaksi keduanya berpengruh tidak nyata terhadap jumlah anakan tanaman bawang merah. Jumlah anakan tanaman bawang merah setelah dilakukan uji lanjut dengan DNMRT taraf 5\% disajikan pada Tabel 2.

Tabel 2. Jumlah anakan bawang merah (batang) umur 45 HST dengan pemberian Trichokompos TKKS terformulasi dan pupuk nitrogen pada lahan gambut.

\begin{tabular}{lllll}
\hline $\begin{array}{l}\text { Tricho- } \\
\text { kompos } \\
\text { (ton/ha) }\end{array}$ & \multicolumn{2}{l}{ Nitrogen(kg) } & $\begin{array}{l}\text { Rata- } \\
\text { rata T }\end{array}$ \\
\cline { 2 - 5 } 15 & 9,00 & $6,44 \mathrm{c}$ & 7,55 & $7,67 \mathrm{~b}$ \\
20 & 9,55 & $8,11 \mathrm{abc}$ & 8,44 & $8,70 \mathrm{ab}$ \\
25 & 9,33 & 8,33 & 8,55 & $8,74 \mathrm{ab}$ \\
30 & 8,55 & 10,33 & 10,00 & $9,63 \mathrm{a}$ \\
\hline Rata-rata & $9,11 \mathrm{~A}$ & $8,30 \mathrm{~A}$ & $8,63 \mathrm{~A}$ & \\
$\mathrm{~N}$ & & & & \\
\hline
\end{tabular}

Angka-angka yang diikuti oleh huruf kecil yang sama atau huruf besar yang sama pada kolom dan baris yang sama berbeda tidak nyata menurut uji Duncan pada taraf 5\%

Tabel 2 menunjukkan bahwa pemberian Trichokompos TKKS terformulasi dan pupuk nitrogen tidak terjadi interaksi secara nyata terhadap jumlah anakan bawang merah, namun pemberian Trichokompos TKKS terformulasi 30 ton/ha dan pupuk kalium $250 \mathrm{~kg} / \mathrm{ha}$ cenderung menghasilkan jumlah anakan tertinggi atau meningkat sebesar $60 \%$, dibandingkan dengan pemberian dosis 15 ton/ha Trichkompos TKKS terformulasi diikuti pupuk nitrogen dosis 250 $\mathrm{kg} / \mathrm{ha}$. Tidak terjadinya interaksi diduga ketersediaan unsur hara $\mathrm{N}$ sudah cukup tinggi di dalam tanah (Tabel 1) ditambah dengan suplai hara N dari Trichokompos TKKS terformulasi, sehingga penambahan hara dari pupuk nitrogen sudah tidak direspon lagi oleh tanaman.

Hasil penelitian Purbiati, et al. (2010) menunjukkan bahwa varietas Bauji berumur 30 HST yang ditanam di lahan gambut dataran rendah menghasilkan jumlah anakan rata-rata 5,29 batang. 
Pemberian Trichokompos TKKS terformulasi 30 ton/ha nyata meningkatkan jumlah anakan bawang merah yaitu 25\% dibandingkan dengan dosis yang terendah yaitu 15 ton/ha. Hal ini disebabkan Trichokompos TKKS terformulasi mampu memberikan hara yang cukup untuk pertumbuhan vegetatif bawang merah terutama terhadap jumlah anakan. Tersedianya hara yang cukup disebabkan oleh Trichokompos TKKS terformulasi telah termineralisasi, dimana nilai C/N Trichokompos terformulasi yaitu 11,7 (Hasil analisa pupuk). Hal ini menunjukkan Trichokompos TKKS terformulasi telah matang sempurna.

Kematangan kompos dapat dilihat dari kandungan karbon dan nitrogen melalui nilai $\mathrm{C} / \mathrm{N}$. Menurut Anisuryani (2008) nilai C/N kompos yang stabil antara 10-30. Kompos memiliki nilai $\mathrm{C} / \mathrm{N}$ yang lebih kecil dari 30 ini menunjukkan kompos sudah termineralisasi, dan nitrogen yang tersedia siap dimanfaatkan tanaman. Novizan (2003) menyatakan bahwa rasio $\mathrm{C} / \mathrm{N}$ rendah maka bahan penyusun kompos lebih mudah terurai secara sempurna sehingga unsur hara lebih tersedia. Refliaty (2013) juga menyatakan kompos yang memiliki $\mathrm{C} / \mathrm{N}$ rendah hingga sedang akan lebih mudah terdekomposisi.

Kandungan hara nitrogen pada Trichokompos TKKS terformulasi dapat merangsang pertumbuhan dan perkembangan tanaman dengan baik sehingga dapat meningkatkan pertumbuhan jumlah anakan bawang merah. Hasil ini sejalan dengan pendapat Elizabet, et a.l (2013) kandungan unsur nitrogen yang tinggi membuat tanaman lebih hijau sehingga dapat meningkatkan proses fotosintesis. Meningkatnya hasil fotosintesis yang ditranslokasikan pada jaringan tanaman akan merangsang tumbuhnya anakan.

Peningkatan jumlah anakan bawang merah juga ditentukan oleh adaptasi varietas dengan lingkungan dimana tanaman bawang merah tersebut dibudidayakan. Varietas yang digunakan dalam penelitian adalah varietas Bauji yang memiliki daya tumbuh paling tinggi bila ditanam pada tanah gambut. Hal ini sejalan dengan penjelasan Purbiati, et al. (2010) menyatakan bahwa varietas Bauji daya tumbuhnya lebih cepat dan paling tinggi (98,87- 98,88\%) serta pertumbuhan jumlah daun, tinggi tanaman dan jumlah anakan yang lebih baik dibandingkan varietas lain yang ditanam pada lahan gambut.

Penambahan pupuk nitrogen memberikan pengaruh yang seragam. Kondisi ini mengindikasikan bahwa peningkatan dosis pupuk tidak diikuti dengan membaiknya pertumbuhan tanaman dan dapat disimpulkan bahwasanya sudah terjadi konsumsi mewah terhadap tanaman yang dibudidayakan. Menurut Schroth dan Sinclair (2003) tanaman yang memperoleh unsur hara dalam jumlah yang optimum serta waktu yang tepat, maka akan tumbuh dan berkembang secara maksimal. Sumarni, et al. (2012) menyatakan bahwa pemupukan nitrogen tidak meningkatkan jumlah anakan bawang merah per tanaman. Lebih lanjut Sumarni, et al. (2012) menyatakan bahwa jumlah anakan lebih banyak ditentukan oleh faktor genetik dari pada faktor pemupukan.

\section{Bobot segar umbi per tanaman sampel}

Hasil sidik ragam menunjukkan bahwa pemberian Trichokompos TKKS terformulasi dan pupuk nitrogen serta interaksi keduanya berpengaruh nyata terhadap bobot segar umbi tanaman bawang merah. Bobot segar umbi tanaman bawang merah setelah dilakukan uji lanjut dengan DNMRT taraf 5\% disajikan pada Tabel 3.

Tabel 3. Bobot segar umbi tanaman sampel bawang merah dengan pemberian Trichokompos TKKS terformulasi dan pupuk nitrogen pada lahan gambut

\begin{tabular}{|c|c|c|c|c|}
\hline \multirow{2}{*}{$\begin{array}{c}\text { Trichok } \\
\text { ompos( } \\
\text { T) } \\
\text { (ton/ha) }\end{array}$} & \multicolumn{3}{|c|}{ Nitrogen $(\mathrm{kg})$} & \multirow{2}{*}{$\begin{array}{l}\text { Rata- } \\
\text { rata } T\end{array}$} \\
\hline & 150 & 250 & 350 & \\
\hline $\begin{array}{l}15 \\
20 \\
25 \\
30\end{array}$ & $\begin{array}{c}21,94 \\
\mathrm{e} \\
23,74 \\
\mathrm{de} \\
38,16 \\
\mathrm{bc} \\
44,86 \\
\mathrm{~b}\end{array}$ & $\begin{array}{c}32,63 \\
\text { bcde } \\
32,63 \\
\text { bcde } \\
32,11 \text { cde } \\
44,96 \mathrm{~b}\end{array}$ & $\begin{array}{c}35,29 \\
\text { bcd } \\
36,50 \mathrm{bc} \\
42,03 \mathrm{bc} \\
72,69 \mathrm{a}\end{array}$ & $\begin{array}{l}29,95 \mathrm{c} \\
30,96 \mathrm{c} \\
37,43 \mathrm{~b} \\
54,17 \mathrm{a}\end{array}$ \\
\hline $\begin{array}{l}\text { Rata- } \\
\text { rata N }\end{array}$ & $\begin{array}{c}32,17 \\
b\end{array}$ & $35,58 b$ & $46,62 \mathrm{a}$ & \\
\hline
\end{tabular}


Angka-angka yang diikuti oleh huruf kecil yang sama pada kolom dan baris yang sama tidak berbeda nyata menurut uji Duncan pada taraf 5\%

Tabel 6 menunjukkan bahwa interaksi Trichokompos TKKS terformulasi dosis 30 ton/ha pada taraf pupuk nitrogen $350 \mathrm{~kg} / \mathrm{ha}$ meningkatkan bobot segar umbi secara nyata. Bobot segar meningkat sebesar $231 \%$ atau dua kali bila dibandingkan dengan interaksi perlakuan Trichokompos TKKS terformulasi dosis 15 ton/ha diikuti dosis pupuk nitrogen 150 $\mathrm{kg} / \mathrm{ha}$. Sedangkan pada interaksi perlakuan lain peningkatannya lebih rendah yaitu $104 \%$ hingga $8,20 \%$ bila dibandingkan dengan kombinasi perlakuan dosis terendah.

Hal ini disebabkan Trichokompos TKKS terformulasi adalah salah satu pupuk organik yang memiliki kemampuan dalam memperbaiki sifat fisik tanah, memperbaiki tata udara dan air tanah. Perbaikan sifat fisik tanah tersebut berdampak positif terhadap pertumbuhan akar dan penyerapan unsur hara (Dinas Tanaman Pangan Provinsi Riau, 2006). Kondisi ini membuat serapan hara nitrogen oleh akar tanaman meningkat sehingga mempengaruhi bobot segar umbi bawang merah.

Bobot segar umbi bawang merah berkolerasi erat dengan parameter serapan hara nitrogen rerata koofisien korelasi $r=0,71$. Korelasi ini menunjukkan bahwa semakin tinggi serapan $\mathrm{N}$ dapat meningkatkan bobot segar umbi bawang merah. Unsur nitrogen mempengaruhi pembentukan sel-sel baru dan unsur kalium yang terdapat pada Trichokompos TKKS terformulasi dapat mempengruhi perkembangan jaringan khususnya pada umbi tanaman bawang merah.

Kalium berperan membantu proses fotosintesis, yaitu pembentukan senyawa organik baru yang diangkut ke organ tempat penimbunan, yaitu umbi. Hal ini sejalan dengan pernyataan Yetti dan Elita (2008) menunjukkan bahwa peran kalium dalam tanaman yakni membantu proses fotosintesa untuk pembentukan senyawa organik baru yang diangkut ke organ penimbunan yakni umbi serta memperbaiki kualitas umbi.

Pemberian Trichokompos TKKS terformulasi dosis 30 ton/ha nyata meningkatkan bobot segar umbi bawang merah. Bobot umbi bawang merah meningkat $80 \%$ dibandingkan pemberian dosis terendah. Hal ini disebabkan Trichokompos TKKS terformulasi memiliki kemampuan menahan air dimana fotosintesis dan metabolisme tanaman tidak hanya dipengaruhi keseimbangan hara akan tetapi juga dipengaruhi ketersediaan air.

Jika kebutuhan air untuk pertumbuhan bawang merah tercukupi maka akar menyerap hara lebih banyak dapat mendukung peningkatan bobot segar umbi bawang merah Carora, et al. (2014) menyatakan bahwa peningkatan berat segar umbi dipengaruhi oleh banyaknya absorbsi air dan penimbunan hasil fotosintesis pada daun untuk ditranslokasikan bagi pembentukan umbi.

Pemberian pupuk nitrogen dosis $350 \mathrm{~kg} / \mathrm{ha}$ nyata meningkatkan bobot segar umbi bawang merah. Bobot segar umbi meningkat $44 \%$ dibandingkan dengan dosis terendah. Hal ini disebabkan pemberian pupuk nitrogen memberkan kontribusi ketersediaan hara nitrogen yang optimal sehingga meningkatkan bobot segar umbi bawang merah. Sumarni dan Roslaini (2010) meyatakan bahwa ketersediaan hara nitrogen yang optimal dalam tanah diperlukan untuk merangsang proses pertumbuhan dan pembentukan umbi bawang merah, disamping hara $\mathrm{P}$ dan $\mathrm{K}$.

\section{KESIMPULAN DAN SARAN}

\section{Kesimpulan}

Berdasarkan hasil penelitian ini, maka dapat disimpulkan beberapa hal sebagai berikut :

1. interaksi Trichokompos TKKS terformulasi 30 ton/ha dan pupuk nitrogen $350 \mathrm{~kg} \mathrm{~N} / \mathrm{ha}$ meningkatkan bobot segar umbi per rumpun sampel secara nyata.

2. Peningkatan dosis Trichokompos TKKS terformulasi dari 15 ke 30 ton/ha meningkatkan tinggi tanaman, jumlah anakan dan bobot segar umbi per rumpun sampel.

3. Peningkatan dosis pupuk nitrogen dari $150 \mathrm{ke}$ $350 \mathrm{~kg} \mathrm{~N} / \mathrm{ha}$ meningkatkan tinggi tanaman dan bobot segar umbi per rumpun sampel.

\section{Saran}

Budidaya bawang merah yang ditanam pada lahan gambut sebaiknya menggunakan pupuk Trichokompos TKKS terformulasi dosis 30 ton/ha 
dan pupuk nitrogen dosis $350 \mathrm{~kg} \mathrm{~N} / \mathrm{ha}$ agar mendapatkan pertumbuhan vegetatif terbaik dan produksi optimal

\section{DAFTAR PUSTAKA}

Anisuryani, 2008. Perbaikan Tanah Media Tanaman Jeruk dengan Berbagai Bahan Organik dalam Bentuk Kompos. Bogor. 2007.

Anom, E. 2008. Efek Residu Pemberian Trichokompos Jerami Padi Terhadap Pertumbuhan dan Produksi Tanaman Sawi (Brassica junsea. L). J. Sagu. 7 (2) : 12. Diakses tanggal 27 Januari 2015.

Anshar, M. 2002. Aplikasi effective microorganism dan pupuk organik hayati untuk meningkatkan hasil bawang merah. J. Agrisains 3 (1) : 41-45.

Badan Pusat Statistik. 2014. Riau dalam Angka. Pekanbaru. Com

Balai Besar Penelitian dan Pengembangan Sumber Daya Lahan Pertanian, 2011. Laporan Tahunan 2011, Konsorsium Penelitian dan Pengembangan PerubahanIklim pada Sektor Pertanian. Balai Besar Penelitian danPengembangan Sumberdaya Lahan Pertanian, Bogor.

Badan Penelitian dan Pengembangan Pertanian. 2011. Peta Lahan Gambut Indonesia sdlp.litbang.deptan.go.id. Akses tgl 09 September 2014.

Carora, F.A, Wicaksono, P.K, Suwasono , Y.B. 2014. Pengaruh Pemberian Bioaktivator Terhadap Pertumbuhan Dan Hasil Tanaman Bawang Merah(Allium Ascolanium L.) J Produksi Tanaman vol. 2 (5) : 434-442

Dahlan, A. K, Puspita. F, Armaini. 2015 Aplikasibeberapa Dosis Tricho-kompos Tandan Kosong Kelapa Sawit (Tkks) Pada Tanaman Pakcoy (Brassica Rapa L.) Jom Faperta vol 2 (1) : 1-10.

Dinas Pertanian Tanaman Pangan Provinsi Riau. 2006. Pemanfaatan Lahan dan Peluang Pengembangan Tanaman Pangan dan Hortikultura Di Lahan Gambut.
Pemerintah Provinsi Riau. Pekanbaru. 435 hal

Elisabeth, W.D, Santosa.M, Herlina.N. 2013 Pengaruh Pemberian Berbagai Komposisi Bahan Organik pada Pertumbuhan danHasil Tanaman Bawang Merah (Allium ascalonicum L.) Jurnal Produksi Tanaman Vol.1(3).

Hidayat I M, Putrasameja S dan Azmi C. 2011. Persiapan Pelepasan Varietas Bawang Merah Umbi dan TSS. Laporan Kegiatan: 1804.17.a3.

Ichwan B. 2007. Pengaruh Dosis Trichokompos Terhadap Pertumbuhan dan Hasil Tanaman Cabe Merah. Jurnal Agronomi, Vol.11 No. 1 Hal. 47-50.

Lakitan, B. 2001. Dasar-Dasar Fisiologi Tumbuhan. PT. Raja Grafindo Persada. Jakarta.

Lingga dan Marsono 2006. Petunjuk Penggunaan Pupuk. Penebar swadaya. Jakarta.

Murniati, Silvina F, Hamzah A. 2010. Pemanfaatan Residu Abu Serbuk Gergaji dan Kascing pada Medium Gambut Setelah Penanaman Tomat Untuk Penanaman Bawang Merah. J. Sagu. Vol.9 No.2: 47-52.

Napitulu, D. dan Winarto, L. 2010. Pengaruh Pemberian Pupuk N dan K Terhadap Pertumbuhan dan Produksi bawang merah. J. Hort. Vol.20. no 1.

Nelvia. 2009. Peningkatan Produksi padi pada tanah gambut yang di sawahkan dengan pemberian amelioran dregs dan fly ash (limbah recauticizing dan abu sisa boiler pembakaran pabrik pulp). Laporan Penelitian Lembaga Penelitian Universitas Riau.

Nelvia, Islan, Sihaan DF. 2012. Pertumbuhan dan Produksi Kedelai Sebagai Tanaman Sela di Kebun Kelapa Sawit pada Lahan Gambut yang di Aplikasi Kompos Tandan Kosong Kelapa Sawit. Prosiding Seminar Nasional dan Rapat Tahunan BKS-PTN Wilayah Barat.

Novizan. 2003. Petunjuk Penggunaan Pupuk yang Efektif. Agromedia Pustaka, Jakarta. 114 hal 
Prasetya, B., S, Kurniawan, dan Febrianingsih. 2009. Pengaruh Dosis dan Frekuensi Pupuk Cair Terhadap Serapan dan Pertumbuhan Sawi ( Brassica junsea L. ) Pada Entisol. Univ. Brawijaya. Malang.

Purbiati T, Umar A dan Supriyanto A. 2010. Pengkajian Adaptasi Varietas-Varietas Bawang Merah pada Lahan Gambut di Kalimantan Barat. BPTP- Kalimantan Barat.

Refliaty, Endriani, Zurhalena. 2013. Efek Aplikasi Berbagai Formula Pupuk Bioorganik Trichokompos Terhadap Hasil dan Serapan Hara Oleh Kedelai pada Tanah Masam. J. Penelitian Universitas Jambi Seri Sains. Vol. 15, No 2: 25-32.

Schroth, G dan F. C. Sinclair. 2003. Tress, Crops and Soil Ferlility: concepts and Research Methods.CABI.464 P.

Silaban L. R, Puspita F, Sampoerno. 2014. Aplikasi Beberapa Dosis Formulasi Trichokompos Berbasis Limbah Sawit Dengan Penambahan Nutrisi Pada Bibit Okulasi Karet (Hevea brasiliensis) di Medium Gambut. Jom Faperta. Vol. 1 No. 2.
Sumarni, N dan Roslaini. 2010. Pengaruh Naungan Plastik Transparan, Kerapatan Tanaman dan Dosis $\mathrm{N}$ terhadap Produksi Umbi Bibit Asal Biji Bawang Merah. J. Hort.20 (1) : 52-59

Sumarni N, Rosliani R, Basuki RS, Hilman Y. 2012. Pengaruh Varietas, Status K-Tanah, Dosis Pupuk Kalium Terhadap Pertumbuhan, Hasil Umbi dan Serapan Hara K Tanaman Bawang Merah. J. Hort. 22(3):233-241.

Sunarlim, Novianti dan Wawan Gunawan. 1998. Pengaruh Pemupukan N Dan Komponen Hasil Kedelai Di Lahan Kering Kabupaten Garut. Penelitian Pertanian. 9 (3): 127-131.

Yetti . H dan Ellita. E. 2008. Penggunaan Pupuk Organik pada Tanaman Bawang merah (Allium ascolanicum.L). J. Sagu Vol. 7 (1) : 13-18

Yulia A E, Murniati dan Fatimah. 2011. Aplikasi Pupuk Organik pada Tanaman Caisim untuk Dua Kali Penanaman. Sagu. Vol.10 No.1: 14-19. 